\title{
EVALUASI STANDARD OPERATIONAL PROCEDURE PELAYANAN RESEP DI PUSKESMAS CIBUNGBULANG KABUPATEN BOGOR PERIODE MARET s/d APRIL 2018
}

\author{
Esa Nylidia ${ }^{* 1}$, Muhammad Afqary ${ }^{1}$, Ariansyah $^{1}$ \\ 1.Program Studi Farmasi Sekolah Tinggi Teknologi Industri dan Farmasi Bogor \\ Korespondensi :avanindrasavioferro@gmail.com
}

\begin{abstract}
ABSTRAK
Pelayanan resep merupakan bagian yang tidak terpisah dari pelayanan kefarmasian di Puskesmas. Evaluasi terhadap standar pelayanan resep di Puskesmas Cibungbulang dilakukan dengan membandingkan pelaksanaan pelayanan resep di Puskesmas dengan Standar pengkajian resep menurut Permenkes No 74 Tahun 2016 tentang standar pelayanan kefarmasian di Puskesmas. Penelitian observasi deskriptif dilakukan terhadap 324 sampel. Data dikumpulkan menggunakan tabel pengamatan. Hasil penelitian menunjukan bahwa tanggal penulisan resep, dosis, jumlah obat, aturan cara dan teknik penggunaan, ketepatan dosis, waktu penggunaan obat, penyiapan /peracikan, penyerahan sudah terlaksana dengan baik dengan persentase sebesar $100 \%$. Sedangkan komponen lain seperti id pasien, paraf dokter, bentuk obat, ketersediaan, efek samping obat, memberi label atau etiket, pemberian informasi obat yang belum memenuhi Standar Pelayanan Kefarmasian di Puskesmas.
\end{abstract}

\section{Kata Kunci : Standar Pelayanan Kefarmasian, SOP, Puskesmas}

\begin{abstract}
Prescription care is an integral part of pharmaceutical care at Primary Health Facility. Evaluation of prescription care standard at Primary Health Facility Cibungbulang was done by comparing the implementation of prescription care in Primary Health Facility with prescription prescribing standard according to Permenkes No 74 of 2016 about standard of pharmaceutical care at Primary Health Facility. A descriptive observational study was conducted on 324 samples. Data were collected using an observation table. The results showed that the date of prescribing, dosage, quantity of drug, rules of procedure and technique of use, accuracy of dose, time of drug use, preparation / compounding, delivery was done well with percentage of $100 \%$. While other components such as patient id, paraf doctor, drug form, availability, drug side effects, label or etiquette, the provision of drug information that has not met the Pharmaceutical Care Standard in Primary Health Facility.
\end{abstract}

Keywords : Standard of Pharmaceutical care, SOP Prescription care, Puskesmas 


\section{PENDAHULUAN}

Kegiatan pelayanan kefarmasian di Puskesmas tidak lepas dari aktivitas pelayanan resep. Pelayanan resep di Puskesmas merupakan satu kesatuan yang tidak terpisahkan dari pelaksanaan upaya kesehatan, yang berperan penting dalam meningkatkan mutu pelayanan kesehatan bagi masyarakat. Pelayanan resep di Puskesmas harus mendukung tiga fungsi pokok Puskesmas, yaitu sebagai pusat penggerak pembangunan berwawasan kesehatan, pusat pemberdayaan masyarakat, dan pusat pelayanan kesehatan strata pertama yang meliputi pelayanan kesehatan perorangan dan pelayanan kesehatan masyarakat. Puskesmas sebagai tempat dilakukannya pelayanan kesehatan yang terdepan sesuai dengan prinsip Puskesmas adalah menciptakan paradigma sehat, pertanggung jawaban wilayah, kemandirian masyarakat, pemerataan, teknologi tepat guna dan keterpaduan dan kesinambungan.

Pelayanan resep di Puskesmas dibawah tanggung jawab langsung Apoteker dan dibantu oleh Tenaga Teknis Kefarmasian (TTK) yang harus dilakukan dengan mengacu ke Peraturan Menteri Kesehatan Republik Indonesia No 74 Tahun 2016 tentang Standar Pelayanan Kefarmasian di Puskesmas.

Dalam alur pelayanan resep, Apoteker wajib melakukan skrining resep yang meliputi skirining administrasi, kesesuaian farmasetik, dan kesesuaian klinis yang sudah diatur dalam Peraturan Menteri Kesehatan Republik Indonesia No 74 Tahun 2016 tentang Standar Pelayanan Kefarmasian di Puskesmas.

Akan tetapi, peningkatan kinerja pelayanan kesehatan dasar yang ada di Puskesmas dilakukan sejalan dengan perkembangan kebijakan yang ada pada berbagai sektor. Adanya kebijakan otonomi daerah dan desentralisasi diikuti pula dengan menguatnya kewenangan daerah dalam membuat berbagai kebijakan. Selama ini penerapan dan pelaksanaan upaya kesehatan dalam kebijakan dasar Puskesmas yang sudah ada sangat beragam antara daerah satu dengan daerah lainnya, namun secara keseluruhan belum menunjukkan hasil yang optimal. (Kemkes 2016)

Maka untuk melakukan pelayanan resep sudah seharusnya Puskesmas memiliki dan menerapkan pelayanan yang sesuai dengan Peraturan Menteri Kesehatan Republik Indonesia No 74 Tahun 2016 tentang Standar
Pelayanan Kefarmasian, sehingga menciptakan mutu pelayanan yang baik dan aman. Masalah yang ada di Puskesmas Cibungbulang Kabupaten Bogor belum terdapat Tenaga Teknis Kefarmasian dan Apoteker yang bertugas dan bertanggung jawab langsung dalam melakukan pelayanan resep. Hal ini yang melatar belakangi peneliti mengamati evaluasi Standard Operational Procedure (SOP) Pelayanan Resep di Puskesmas Cibungbulang Kabupaten Bogor yang akan dibandingkan dengan Peraturan Menteri Kesehatan Republik Indonesia No 74 Tahun 2016 tentang standar pelayanan kefarmasian di Puskesmas. Maka untuk melakukan pelayanan resep sudah seharusnya Puskesmas memiliki dan menerapkan pelayanan yang sesuai dengan Peraturan Menteri Kesehatan Republik Indonesia No 74 Tahun 2016 tentang Standar Pelayanan Kefarmasian, sehingga menciptakan mutu pelayanan yang baik dan aman. Masalah yang ada di Puskesmas Cibungbulang Kabupaten Bogor belum terdapat Tenaga Teknis Kefarmasian dan Apoteker yang bertugas dan bertanggung jawab langsung dalam melakukan pelayanan resep. Hal ini yang melatar belakangi peneliti mengamati evaluasi Standard Operational Procedure (SOP) Pelayanan Resep di Puskesmas Cibungbulang Kabupaten Bogor yang akan dibandingkan dengan Peraturan Menteri Kesehatan Republik Indonesia No 74 Tahun 2016 tentang standar pelayanan kefarmasian di Puskesmas.

\section{Pelayanan Farmasi}

Pelayanan kefarmasian merupakan kegiatan yang terpadu dengan tujuan untuk mengidentifikasi, mencegah dan menyelesaikan masalah obat dan masalah yang berhubungan dengan kesehatan. Tuntutan pasien dan masyarakat akan peningkatan mutu Pelayanan Kefarmasian, mengharuskan adanya perluasan dari paradigma lama yang berorientasi kepada produk (drug oriented) dengan filosofi pelayanan kefarmasian (pharmaceutical care).

\section{Resep}

Resep merupakan permintaan tertulis dari dokter kepada instalasi farmasi untuk menyiapkan, membuat, meracik, dan menyerahkan obat untuk pasien. Dokter harus menulis resep dengan jelas dan lengkap, jika resep yang diterima oleh Apoteker tidak jelas dan lengkap maka isi resep harus dikonfirmasi ulang ke dokter penulis resep. Pada umumnya, resep memiliki ukuran panjang 15 hingga $20 \mathrm{~cm}$ 
dan lebar 10 hingga $12 \mathrm{~cm}$. Lembar resep pada umumnya berbentuk persegi panjang (Jas, 2009).

Resep terdiri dari 4 jenis, antara lain resep standar (R/. Officinalis), yaitu resep yang komposisinya telah dibakukan dan dituangkan ke dalam buku farmakope atau buku standar lainnya; resep magistrales (R/. Poliklinik farmasi), yaitu resep yang sudah dimodifikasi atau diformat oleh dokter, bisa berupa campuran atau tunggal yang diencerkan dalam pelayanannya harus diracik; resep medicinal, yaitu resep obat jadi, bisa berupa obat paten, merek dagang maupun generik, dalam pelayanannya tidak mangalami peracikan; resep obat generik, yaitu penulisan resep obat dengan nama generik dalam bentuk sediaan dan jumlah tertentu. Dalam pelayanannya, dapat mengalami peracikan atau tidak (Jas, 2009).

\section{Penulisan Resep}

Penulisan resep artinya pengaplikasian pengetahuan dokter dalam memberikan obat kepada pasien melalui kertas resep menurut kaedah dan peraturan yang berlaku, diajukan secara tertulis kepada Apoteker di apotek agar obat diberikan sesuai dengan yang tertulis. Pihak apotek terutama Apoteker berkewajiban melayani secara cermat, memberi informasi terutama menyangkut penggunaan dan mengoreksinya bila terjadi kesalahan dalam penulisan. Dengan demikian pemberian obat lebih rasional yang artinya tepat, aman, efektif dan ekonomis (Jas, 2009).

\section{Standard Operational Procedure (SOP)}

Setiap perusahaan bagaimanapun bentuk dan apapun jenisnya, membutuhkan sebuah panduan untuk menjalankan tugas dan fungsi setiap elemen atau unit perusahaan. Standard Operational Procedure (SOP) adalah sistem yang disusun untuk memudahkan, merapihkan dan menertibkan pekerjaan.

\section{SOP Alur Pemberian Obat Kepada Pasien dan Pelabelan di Puskesmas Cibungbulang Kabupaten Bogor}

1. Standard Operational Procedure (SOP) pelayanan resep di Puskesmas Cibungbulang Kabupaten Bogor adalah sebagai berikut :

a. Menyiapkan alat untuk meracik obat dan alat tulis, menyiapkan obat sesuai dengan perkiraan kebutuhan pada hari itu melalui buku harian obat. b. Memberikan daftar i = obat yang tidak tersedia dan daftar obat baru di ruangan pelayanan obat kepada petugas medis (sewaktu waktu ada perubahan daftar).

c. Di sediakan tempat untuk meletakan resep dan di beri tulisan yang jelas.

d. Petugas mengambil resep sesuai urutan dan diberi tulisan yang jelas.

e. Petugas membaca dan meneliti resep yang diterima dengan berpedoman pada $5 \mathrm{~B}+1 \mathrm{~W}$ (Benar obat, Benar pasien, Benar Dosis, Benar cara Pemberian Obat, Benar Waktu Pemberian Obat, dan waspada inkompatibilitas.)

f. Apabila resep belum benar menurut pedoman $5 \mathrm{~B}+1 \mathrm{~W}$ konsultasikan kembali pada penulisan resep.

g. Bila resep sudah benar dan obat tersedia makan obat disiapkan dengan resep.

h. Beri etiket dan label yang sesuai dengan resep, dengan mencantumkan nama pasien, tanggal pembuatan resep, cara panggunaan obat, jumlah obat yang harus di konsumsi dan instruksi lain sesuai perintah resep.

i. Obat sudah di beri etiket dan label dikemas dan diteliti kembali untuk diserahkan kepada pasien.

j. Berikan obat kepada pasien sesuai nama, umur, dan alamat pasien lalu jelaskan cara penggunaan obat dan efek samping obat serta cara penyimpanan obat di rumah.

k. Tanyakan pada pasien apakah penjelasan yang di berikan sudah mengerti dan tanyakan apakah ada hal lain yang ingin di tanyakan berkenaan dengan pemakaian obat.

1. Petugas obat meminta nomor telepon pasien/keluarga yang bisa di hubungi.

m. Ucapkan terima kasih dan senyum.

2. Standard Operational Procedure (SOP) sesudah pelayanan resep di Puskesmas Cibungbulang Kabupaten Bogor adalah sebagai berikut :

a. Petugas mengembalikan dan merapikan obat pada tempatnya lalu menghitung pengeluaran obat yang ada di buku harian.

b. Jenis obat yang akan habis di catatat untuk di mintakan ke gudang obat di Puskesmas. 
56 | Esa Nylidia et al. ( Evaluasi Standard Operational Procedure ... )

c. Jika obat tidak ada maka di konfirmasikan besok paginya kepada petugas medis.

d. Petugas obat membersihkan ruang pelayanan.

e. Mencatat jumlah obat yang keluar dan data pasien.

f. Rekapitulasi bulanan pengeluaran obat LPLPO setiap kabupaten bogor.

1. Alur Pemberian Resep di Puskesmas

Cibungbulang kabupaten Bogor : g. Petugas obat membersihkan mortir dan stamper.

h. Dalam keadaan mendesak untuk obatobat yang habis dapat segara dimintakan ke unit Dinas Kesehatan kabupaten bogor.

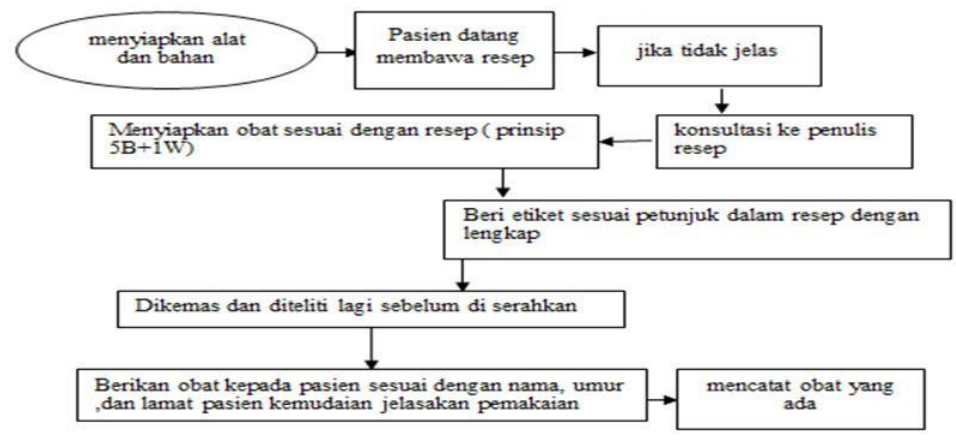

Gambar 1. Alur Pelayanan Resep

\section{SOP Peresepan Obat di Puskesmas Cibungbulang Kabupaten Bogor.}

1. Menulis resep pada lembar resep.

2. Menuliskan dengan tulisan yang jelas dan dapat dibaca serta menggunakan istilah dan singkatan yang lazim digunakan.

3. Mengenali obat - obatan yang masuk dalam kategori LASA untuk menghindari kesalahaan pembaca oleh tenaga kesehatan lainnya.

4. Memastikan resep sudah memenuhi kelengkapan suatu resep dikirim ke farmasi, yaitu :

a. Nama pasien

b. Umur pasien

c. Alamat pasien

d. Nama dokter

e. Memastikan adanya riwayat alergi obat

f. Nama obat dan bentuk obat

g. Jumlah sediaan

h. Bila obat berupa racikan dituliskan setiap jenis/ bahan.

i. Pencampuran beberapa dalam suatu sediaan tidak dianjurkan, kecuali dalam bentuk sediaan campuran tersebut terbukti efektif dan aman.

j. Dalam resep tertulis dosis obat, nomero, signa, bentuk obat serta waktu minum obat.
SOP Pemberian Informasi Obat di Puskesmas Cibungbulang Kabupaten

Bogor.

1. Petugas obat memanggil nama pasien dan memastikan identitas dan alamat pasien yang lengkap.

2. Petugas memeriksa ulang identitas pasien.

3. Petugas obat memeriksa bahwa yang menerima adalah pasien atau keluarga.

4. Petugas memastikan kendala bahasa dalam penyampaian obat.

5. Petugas obat menyerahkan obat disertai pemberian informasi obat.

6. Petugas obat memberikan informasi cara penggunaan obat dan efek samping obat.

7. Petugas obat mengkonfirmasikan apabila ada alergi obat segera kembali ke pelayanan kesehatan untuk ditindak lanjuti.

8. Petugas obat menerima/keluarga pasien mengulang cara penggunaan obat yang telah disampaikan.

9. Petugas memastikan pasien memahami informasi obat yang telah disampaikan dengan cara meminta pasien untuk mengulang informasi yang sudah diberikan. Petugas obat meminta pasien untuk menandatangani resep. 
$57 \mid$ Esa Nylidia et al. ( Evaluasi Standard Operational Procedure ... )

\section{Pendekatan dan Jenis Penelitian}

Desain penelitian ini adalah deskriptif dengan dilakukan pengamatan langsung pelaksanaan SOP pelayanan resep di Puskesmas Cibungbulang Kabupaten Bogor dan mengamati kesesuaian standar pengkajian resep menurut Peraturan Menteri Kesehatan Republik Indonesia No 74 Tahun 2016 tentang Standar Pelayanan Kefarmasian di Puskesmas. Pengumpulan data dilakukan dengan metode observasi langsung dan wawancara. Data disajikan dalam bentuk tabel. Perbandingan pengamatan antara SOP pelayanan resep di Puskesmas Cibungbulang Kabupaten Bogor dengan standar pengkajian resep menurut Peraturan Menteri Kesehatan Republik Indonesia No 74 Tahun 2016 tentang Standar Pelayanan Kefarmasian di Puskesmas. Hasilnya ditampilkan dalam bentuk persentase.

\section{Objek Pengamatan}

Objek pengamatan adalah SOP, pelayanan resep di instalasi rawat jalan di Puskesmas Cibungbulang Kabupaten Bogor.

\section{Populasi dan Sampel \\ Populasi}

Populasi dari penelitian ini adalah 324 total resep yang dikumpulkan pada periode maret april 2018.

\section{Sampel}

Semua total populasi di jadikan sampel ( total sampilng ).

\section{Pengumpulan data}

Pengumpulan data dilakukan dengan cara pengamatan langsung terkait pelayanan resep di Puskesmas Cibungbulang Kab.Bogor, mengamati SOP pelayanan resep kemudian dibandingkan dengan Permenkes RI No 74 Tahun 2016 tentang pelayanan kefarmasian untuk melengkapi data yang sudah di dapat juga dilakukan wawancara langsung kepada petugas pelayanan kefarmasian di Puskesmas Cibungbulang Kab.Bogor.

\section{Kerangka Konsep}

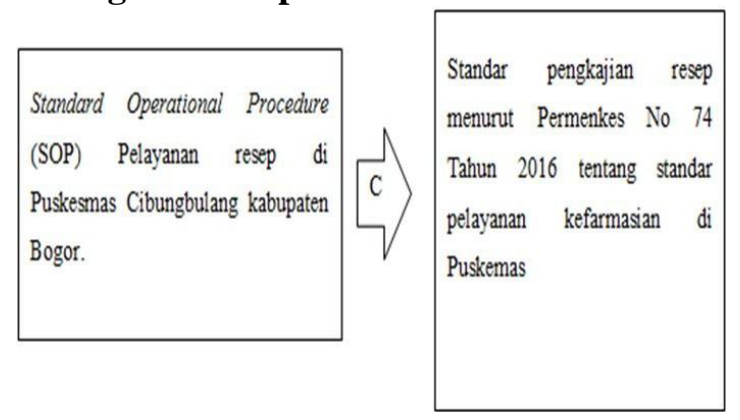

Gambar 2. Kerangka Konsep

\section{Distribusi Jumlah Resep Berdasarkan Layanan Klinik di Puskesmas Cibungbulang Kabupaten Bogor}

Distribusi jumlah resep berdasarkan layanan klinik di Puskesmas Cibungbulang Bogor sebanyak 324 resep yang terdiri dari layanan poli dewasa, poli gigi, poli anak, poli lansia yang dilakukan selama 14 hari dapat dilihat pada tabel berikut :

Tabel 1. Total jumlah resep dari 4 Pelayanan di Puskesmas

\begin{tabular}{|llcc} 
No & $\begin{array}{c}\text { Permenkes No 74 tentang standar } \\
\text { Pelayanan kefarmasian di } \\
\end{array}$ & \multicolumn{1}{c}{$\begin{array}{c}\text { Total resep yang } \\
\text { Puskesmas }\end{array}$} & $\begin{array}{c}\text { Persentase } \\
(\mathbf{\%}) \mathbf{N}=\mathbf{3 2 4}\end{array}$ \\
\hline $\mathbf{1}$ & Id pasien & 129 & $38,81 \%$ \\
$\mathbf{2}$ & Paraf dokter & 120 & $37,03 \%$ \\
$\mathbf{3}$ & Tanggal resep & 324 & $100 \%$ \\
$\mathbf{4}$ & Ruang/ unit asal resep & 0 & $0 \%$ \\
\hline
\end{tabular}


58 | Esa Nylidia et al. ( Evaluasi Standard Operational Procedure ... )

Persentase dari 324 resepyang terbagi dari 4 layanan klinik di Puskesmas Cibungbulang Bogor dapat dilihat dari grafik sebagai berikut :

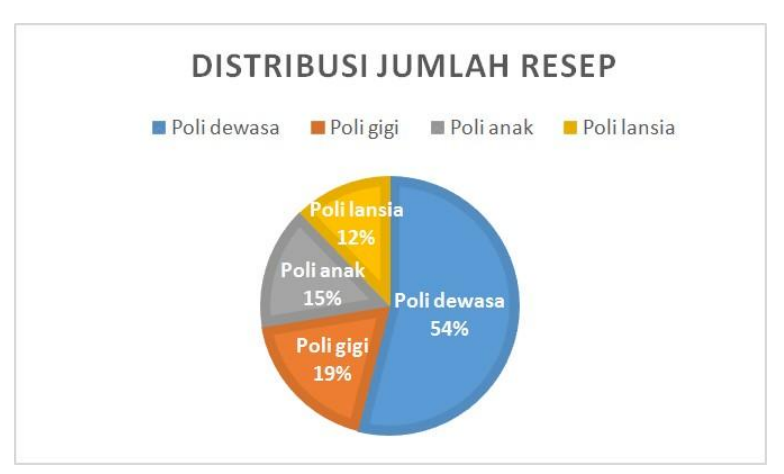

Persentase Data Hasil Evaluasi Pelayanan Resep Dari Aspek Administrasi

Pelaksanaan SOP pelayanan resep dalam aspek administrasi di Puskesmas Cibungbulang Kabupaten Bogor dapat dilihat pada tabel berikut :

\section{Gambar 3. Distribusi Jumlah Resep}

Tabel 1. Persentase Hasil Data Evaluasi Pelayanan Resep Dari Aspek Administrasi

\begin{tabular}{|c|c|c|c|}
\hline No & $\begin{array}{c}\text { Permenkes No } 74 \text { tentang standar } \\
\text { Pelayanan kefarmasian di } \\
\text { Puskesmas }\end{array}$ & $\begin{array}{c}\text { Total resep yang } \\
\text { memenuhi peraturan }\end{array}$ & $\begin{array}{l}\text { Persentase } \\
(\%) \mathrm{N}=324\end{array}$ \\
\hline 1 & Id pasien & 129 & $38,81 \%$ \\
\hline 2 & Paraf dokter & 120 & $37,03 \%$ \\
\hline 3 & Tanggal resep & 324 & $100 \%$ \\
\hline 4 & Ruang/ unit asal resep & 0 & $0 \%$ \\
\hline
\end{tabular}

Berdasarkan tabel diatas diperoleh data hasil pelaksanaan pelayanan resep terkait administrasi di Puskesmas Cibungbulang Kabupaten Bogor yang sudah memenuhi standar pengkajian resep menurut Peraturan Menteri Kesehatan Republik Indonesia No 74 Tahun 2016 tentang standar pelayanan kefarmasian di Puskesmas adalah tanggal resep telah terlaksana sebesar $100 \%$. Dan yang belum dilakukan sepenuhnya id pasien sebesar $38,81 \%$, paraf dokter telah terlaksana sebesar $37,03 \%$ untuk ruang/unit asal resep sama sekali belum diterapkan di Puskesmas Cibungbulang Kabupaten Bogor.
Dikarenakan menurut informasi awal di Puskesmas Cibungbulang Kabupaten Bogor belum terdapat Apoteker dan Tenaga Teknis Kefarmasian (TTK) dan rekaman terhadap pengkajian resep.Terkait ruang/unit asal resep belum diterapkan di Puskesmas Cibungbulang Kabupaten Bogor.

\section{Persentase Hasil Data Evaluasi Pelayanan Resep Dari Aspek Persyaratan Farmasetika}

Pelaksanaan SOP pelayanan resep dalam aspek persyaratan farmasetika di Puskesmas Cibungbulang Kabupaten Bogor dapat dilihat pada tabel berikut :

\section{Tabel 2. Persentase Hasil Data Evaluasi Pelayanan Resep Dari Aspek Persyaratan} Farmasetika

\begin{tabular}{|llcc|} 
No & $\begin{array}{c}\text { Permenkes No 74 tentang standar } \\
\text { Pelayanan kefarmasian di Puskesmas }\end{array}$ & $\begin{array}{c}\text { Total resep yang } \\
\text { memenuhi peraturan }\end{array}$ & $\begin{array}{c}\text { Persentase } \\
(\boldsymbol{\%}) \mathbf{N = 3 2 4}\end{array}$ \\
\hline 1 & Bentuk Sediaan & 180 & $55,5 \%$ \\
\hline 2 & Kekuatan Sediaan & 0 & $0 \%$ \\
\hline 3 & Dosis & 324 & $100 \%$ \\
\hline
\end{tabular}


59 |Esa Nylidia et al. ( Evaluasi Standard Operational Procedure ... )

\begin{tabular}{clccc}
4 & Jumlah obat & 324 & $100 \%$ \\
\hline 5 & Stabilitas & 0 & $0 \%$ \\
6 & Ketersediaan & 150 & $46,29 \%$ \\
7 & Aturan cara dan penggunaan obat & 324 & $100 \%$ \\
\hline 8 & Inkompatibilitas & 0 & 0 \\
\hline
\end{tabular}

Berdasarkan tabel diatas diperoleh data hasil evaluasi pelayanan resep terkait persyaratan farmasetika yang sudah sesuai dengan standar pelayanan pengkajian resep menurut Peraturan Menteri Kesehatan Republik Indonesia No 74 Tahun 2016 tentang standar pelayanan kefarmasian di Puskesmas adalah dosis, jumlah obat, aturan cara dan teknik penggunaan sudah terlaksana dengan persentase sebesar $100 \%$. Untuk bentuk sediaan $55,5 \%$, ketersediaan $46,29 \%$ belum sepenuhnya dilakukan. Dan untuk sia (SDM).

kekuatan sediaan stabilitas , dan inkompatibilitas sama sekali belum diterapkan di Puskesmas Cibungbulang Kabupaten Bogor.
Dari data tersebut menunjukan hasil yang belum dilakukan sepenuhnya dan yang belum dilakukan sama sekali dikarenakan belum terdapat Apoteker dan Tenaga Teknis Kefarmasian (TTK) dan kurangnya Sumber Daya Manusia (SDM).

\section{Persentase Data Hasil Evaluasi Pelayanan Resep Dari Aspek Persyaratan Klinis}

Pelaksanaan SOP pelayanan resep dalam aspek persyaratan Klinis di Puskesmas Cibungbulang Kabupaten Bogor dapat dilihat pada tabel berikut :

\section{Tabel 3. Persentase Hasil Data Evaluasi Pelayanan Resep Dari Aspek Persyaratan Klinis}

\begin{tabular}{|c|c|c|c|}
\hline NO & $\begin{array}{c}\text { Permenkes No } 74 \text { tentang standar } \\
\text { Pelayanan kefarmasian di } \\
\text { Puskesmas }\end{array}$ & $\begin{array}{c}\text { Total resep yang } \\
\text { memenuhi peraturan }\end{array}$ & $\begin{array}{l}\text { Persentase } \\
(\%) \mathrm{N}=324\end{array}$ \\
\hline 1 & Ketetapan indikasi & 0 & $0 \%$ \\
\hline 2 & Ketetapan dosis & 324 & $100 \%$ \\
\hline 3 & Waktu penggunaan obat & 324 & $100 \%$ \\
\hline 4 & Duplikasi pengobatan & 0 & $0 \%$ \\
\hline 5 & Alergi & 0 & $0 \%$ \\
\hline 6 & Interaksi obat & 0 & $0 \%$ \\
\hline 7 & Efek samping obat & 190 & $58,64 \%$ \\
\hline 8 & Kontra indikasi & 0 & $0 \%$ \\
\hline 9 & Efek adiktif & 0 & $0 \%$ \\
\hline
\end{tabular}

Berdasarkan tabel diatas diperoleh data hasil evaluasi pelayanan resep terkait persyaratan klinis berdasarkan yang sudah sesuai dengan standar pelayanan pengkajian resep menurut Peraturan Menteri Kesehatan Republik Indonesia No 74 Tahun 2016 tentang standar pelayanan kefarmasian di Puskesmas adalah ketepatan dosis, waktu penggunaan obat sudah terlaksana dengan baik dengan persentase sebesar $100 \%$. Untuk efek samping obat sepenuhnya belum dilakukan di Puskesmas
Cibungbulang Kabupaten Bogor dengan persentase sebesar $58,64 \%$. dan untuk ketepatan indikasi, duplikasi pengobatan, alergi Interaksi Obat, kontra indikasi, efek adiktif sama sekali belum dilakukan di Puskesmas Cibungbulang Kabupaten Bogor. dari data hasil tersebut yang belum dilakukan sepenuhnya maupun yang belum dilakukan sama sekali dikarenakan belum terdapat Apoteker dan Tenaga Teknis Kefarmasian (TTK) dan kekurangan Sumber Daya Manusia (SDM). 
60 | Esa Nylidia et al. ( Evaluasi Standard Operational Procedure ... )

Persentase Data Hasil Evaluasi Pelayanan Resep Dari Aspek Penyerahan Obat /Dispensing

Pelaksanaan SOP pelayanan resep dalam aspek penyerahan obat/dispensing di
Puskesmas Cibungbulang Kabupaten Bogor dapat dilihat pada tabel berikut :

Tabel 4. Persentase Hasil Data Evaluasi Pelayanan Resep Dari Aspek Penyerahan obat/ Dispensing

\begin{tabular}{|llcc} 
No & $\begin{array}{c}\text { Permenkes No 74 tentang standar } \\
\text { Pelayanan kefarmasian di } \\
\text { Puskesmas }\end{array}$ & $\begin{array}{c}\text { Total resep yang } \\
\text { memenuhi peraturan }\end{array}$ & $\begin{array}{c}\text { Persentase } \\
(\mathbf{\%}) \mathbf{N}=\mathbf{3 2 4}\end{array}$ \\
\hline 1 & Penyiapan /peracikan & 324 & $100 \%$ \\
\hline 2 & Mamberi label/ etiket & 210 & $64,81 \%$ \\
\hline 3 & Penyerahan & 324 & $100 \%$
\end{tabular}

Berdasarkan tabel diatas diperoleh data hasil evaluasi pelayanan resep terkait penyerahan obat/dispensing yang sudah memenuhi syarat dengan standar pelayanan pengkajian resep menurut Peraturan Menteri Kesehatan Republik Indonesia No 74 Tahun 2016 tentang standar pelayanan kefarmasian di Puskesmas adalah penyiapan/peracikan, penyerahan sudah terlaksana dengan persentase sebesar $100 \%$. Untuk pemberian label/ etiket belum sepenuhnya dilakukan dengan persentase sebesar 64,81\%. Dikarenakan di Puskesmas
Cibungbulang Kabupaten Bogor belum tersedia label ataupun etiket khusus untuk obat luar ataupun obat dalam.

\section{Persentase Data Hasil Evaluasi Pelayanan Resep Dari Aspek Pemberian Informasi Obat}

Pelaksanaan SOP pelayanan resep dalam aspek Pemberian Informasi Obat di Puskesmas Cibungbulang Kabupaten Bogor dapat dilihat pada tabel berikut :

\section{Tabel 5.Persentase Hasil Data Evaluasi Pelayanan Resep Dari Aspek Pemberian Informasi} Obat.

\begin{tabular}{|c|c|c|c|}
\hline No & $\begin{array}{c}\text { Permenkes No } 74 \text { tentang standar } \\
\text { kefarmasian di Puskesmas }\end{array}$ & $\begin{array}{c}\text { Total resep yang } \\
\text { memenuhi peraturan }\end{array}$ & $\begin{array}{l}\text { Persentase } \\
(\%) \mathrm{N}=324\end{array}$ \\
\hline 1 & Pemberian informasi obat & 300 & $92,59 \%$ \\
\hline
\end{tabular}

Berdasarkan tabel diatas diperoleh data hasil evaluasi pelayanan resep terkait penyerahan obat/dispensing yang sudah memenuhi syarat dengan standar pelayanan pengkajian resep menurut Peraturan Menteri Kesehatan Republik Indonesia No 74 Tahun 2016 tentang standar pelayanan kefarmasian di Puskesmas adalah pemberian informasi obat belum sepenuhnya terlaksana dengan persentase sebesar 92,59\%. Dikarenakan belum terdapat Apoteker dan Tenaga Teknis Kefarmasian (TTK).

\section{SIMPULAN}

1. Hasil evaluasi pelaksanaan Pelayanan resep di Puskesmas Cibungbulang Kabupaten Bogor yang sudah memenuhi syarat berdasarkan standar pengkajian resep menurut Peraturan Menteri Kesehatan
Republik Indonesia No 74 Tahun 2016 tentang standar pelayanan kefarmasian di Puskesmas antara lain tanggal penulisan resep, dosis, jumlah obat, aturan cara dan teknik penggunaan, ketepatan dosis, waktu penggunaanobat, menyiapkan/meracik, menyerahkan sudah terlaksana dengan baik dengan persentase sebesar $100 \%$.

2. Hasil evaluasi pelaksanaan Pelayanan resep di Puskesmas Cibungbulang Kabupaten Bogor yang belum memenuhi syarat berdasarkan standar pengkajian resep menurut Peraturan Menteri Kesehatan Republik Indonesia No 74 Tahun 2016 tentang standar pelayanan kefarmasian di Puskesmas antara lain id pasien sebesar $(39,81 \%)$, paraf dokter $(37,03 \%)$, bentuk obat $(55,5 \%)$, ketersediaan $(46,29 \%)$, efek 
samping obat $(58,64 \%)$, memberi label atau etiket $(64,81 \%)$, pemberian informasi obat $(92,59 \%)$.

\section{SARAN}

1. Rekrutmen Tenaga Teknis Kefarmasian (TTK) dan Apoteker mutlak diperlukan guna mendukung pelayanan resep yang optimal di Puskesmas Cibungbulang Kab.Bogor.

2. SOP pelayanan resep segara di revisi disesuaikan dengan Peraturan Menteri Kesehatan Republik Indonesia No 74 Tahun 2016 tentang standar pelayanan kefarmasian di Puskesmas.

\section{DAFTAR PUSTAKA}

[1]. Departemen Kesehatan RI, 2004.

Keputusan Menteri Kesehatan

Republik Indonesia Nomor

1197/Menkes/SK/X/2004, tentang Standar Pelayanan Farmasi di Rumah Sakit, Jakarta.

[2]. Kemkes,2009. “Pelayanan Puskesmas” Jakarta Peraturan Menteri Republik Indonesia.

[3]. Kemkes RI, 2009.Peraturan Menteri Kesehatan Republik Indonesia NO.51 tentang. Standar Pelayanan Kefarmasian di Puskesmas “.Jakarta

: Departemen Kesehatan RI.

[4]. Kemkes 2016. "Peraturan Menteri Kesehatan Republik Indonesia Nomor 74 Tahun 2016 tentang Standar Pelayanan Kefarmasian di Puskesmas”,Jakarta Peraturan Menteri Republik Indonesia.

[5]. Hartatik, Indah Puji. 2014. Buku Pintar S.O.P (Standard Operational Procedure). Flashbokk. Jogjakarta. hlm 35.

[6]. Jas, A., 2009. Perihal Resep \& Kelengkapan Resep. 2nd ed. Medan, Indonesia : Universitas Sumatra Utara press, 1-15 
[7]. Departemen Kesehatan RI, 2004. Keputusan Menteri Kesehatan Republik Indonesia Nomor 1197/Menkes/SK/X/2004 tentang Standar Pelayanan Farmasi di Rumah Sakit. Jakarta.

[8]. Jones, Charles O. 1994.

Pengertian Evaluasi.

Penerjemah Ricky

Istamto. Jakarta,

Rajawali. hlm 355

[9]. Sarono.Naskah Layanan Konseling Perorangan, Layanan Bimbingan dan KonselingKelompok. (Jakarta: Departemen Pendidikan Nasional, 2006). hlm 4.

[10] Sailendra, Annie. 2015. Langkah - Langkah Praktis Membuat SOP, Cetakan Pertama, Trans Idea Publishng., Yogyakarta. hlm 170. 